\title{
Effect of Birthweight, Illness History, and Dietary Pattern, on the Incidence of Anemia in Children Under-Five at Tasikmadu Health Center, Karanganyar, Central Java
}

\author{
Yeni Anggraini, ${ }^{1,2)}$, Harsono Salimo3), Didik Tamtomo4) \\ 1) Diploma Program in Health Sciences Mitra Husada, Karanganyar, Central Java \\ 2) Masters Program in Public Health, Sebelas Maret University \\ 3) Department of Pediatrics, Faculty of Medicine, Sebelas Maret University \\ 4) Department of Anatomy, Faculty of Medicine, Sebelas Maret University
}

\begin{abstract}
Background: The first five years of life is often regarded as "golden age period" of development. During this period physical, motor, intellectual, emotional, language, and social development proceed rapidly in children. Brain tissues grow fast to reach $80 \%$ of adult brain weight. Anemia occuring during this period can affect health, as well as cognitive and physical development in children. This study aimed to determine the effects of birthweight, illness history, dietary pattern, maternal education, and family income on the incidence of anemia in children under-five years of age.

Subject and Method: This was an analytic observational study using case control design. The study was carried out at Karanganyar District, Central Java, from February to April 2017. A sample of 110 subjects was selected for this study, consisting of 35 children under-five years of age with anemia and 75 children of the same age without anemia. The independent variables were birthweight, illness history, dietary pattern, maternal education, and family income. The dependent variable was anemia. The data were collected by a set of questionnaire. Hemoglobin concentration was measured by $\mathrm{Hb}$ meter. The data were analyzed by path analysis on Stata 13 .

Results: Anemia in children under-five was directly affected by illness history $(b=2.50$; 95\% CI = 1.06 to $3.95 ; \mathrm{p}=0.001 ;)$, dietary pattern $(\mathrm{b}=-1.89 ; 95 \% \mathrm{CI}=-3.39$ to $-0.39 ; \mathrm{p}=0.013 ;)$, and birthweight $(\mathrm{b}=-0.97 ; 95 \% \mathrm{CI}=-2.07$ to $0.13 ; \mathrm{p}=0.083)$. Anemia in children under-five was indirectly affected by maternal educational $(b=1.09 ; 95 \% \mathrm{CI}=0.14-2.04 ; \mathrm{p}=0.024)$ and family income ( $b=-0.90 ; 95 \% \mathrm{CI}=-1.78$ to $0.02 ; \mathrm{p}=0.044)$.

Conclusion: Anemia in children under-five is directly affected by illness history, dietary pattern, and birthweight. It is indirectly affected by maternal educational and family income.
\end{abstract}

Keywords : Anemia, birthweight, illness history, dietary pattern, children under-five

\section{Correspondence:}

Yeni Anggraini. Masters Program in Public Health, Sebelas Maret University, Jl. Ir. Sutami 36 A, Surakarta 57126, Indonesia. Email : yenni.anggrainie@gmaill.com. Mobile : 085712329100

\section{LATAR BELAKANG}

Usia balita merupakan usia terpenting dari seluruh tahapan perkembangan. Dalam periode ini perkembangan fisik, motorik, intelektual, emosional, bahasa dan sosial anak sangat cepat. Jaringan otak juga akan tumbuh pesat mencapai $80 \%$ berat otak orang dewasa (Veria dan Mubarokah 2012). Terkait hal tersebut, pola asuh gizi menjadi salah satu hal yang sangat penting diper- hatikan, karena asupan nutrisi sangat mempengaruhi pertumbuhan sel-selotak yang menjadi dasar kecerdasan setiap individu. Pemberian Makanan Pendamping Asi (MP-ASI) yang tidak tepat membuat anak-anak rentan mengalami anemia (Zuffoet al., 2016).

WHO bersama Pusat Pengendalian dan Pencegahan Penyakit menyatakan bahwa prevalensi anemia pada anak di 
bawah usia 5 tahun mencapai $34.4 \%$ (16.3\% pada anak laki-laki dan 18.1\% pada anak perempuan) (Pasricha, 2014). Penelitian terdahulu, yang dilakukan oleh $\mathrm{Al}$ Hasawiet al., (2015) di Saudi Arabia juga menyatakan bahwa dari 500 bayi usia 6 sampai 24 bulan, masih ada 246 bayi yang mengalami anemia defisiensi besi. Pada tahun 2012, berdasarkan Data Survei Kesehatan Rumah Tangga (SKRT) prevalensi anemia pada balita di Indonesia masih sebesar 40.5\% (Kemenkes RI, 2013). Tahun 2013, angka kejadian anemia pada Balita di Jawa Tengah juga masih sangat tinggi, mencapai 57.1\% (Dinkes Prov. Jateng, 2014).

Anemia yang terjadi pada masa golden age period akan mempengaruhi kesehatan, perkembangan kognitif dan fisik anak. Hal ini karena, besi (Fe) sangat diperlukan untuk pembelahansel dan sintesis hemoglobin, besi juga beperan untuk sintesis DNA, neurotransmiter dan sitokrommitokondria. Jadi, kekurangan besi dapat menggangu sintesis DNA, mempengaruhi kekebalan, meningkatkan risiko infeksi dan kematian bayi (Zuffo et al., 2016). Pada saat dilahirkan, bayi memiliki cadangan besi yang didapatkan dari ibunya selama dalam kandungan. Sebagian besar proses transfer zat besi dari ibu ke janin terjadi pada bulan-bulan akhir kehamilan, dengan demikian bayi yang lahir prematur dan bayi dengan Berat Badan Lahir Rendah (BBLR) lebih rentan mengalami anemia.

Selain itu, pertumbuhan pascakelahiran bayi prematur dan BBLR, lebih cepat dibandingkan dengan bayiyang lahir cukup bulan. Oleh karena itu, jika dalam pemberian nutrisitidak diberikan tambahan suplementasi zat besi, maka mereka lebih cepatmengalami anemia (WHO, 2004). Karanganyar, merupakan salah satu Kabupaten di Jawa Tengah yang menyumbangkan angka BBLR cukup banyak. Pada tahun 2014, terdapat 510 bayi yang lahir hidup dengan BBLR, angka ini meningkat menjadi 647 pada tahun 2015. Wilayah yang mempunyai angka kejadian BBLR paling banyak adalah wilayah Tasikmadu, yaitu dari 25 kasus pada tahun 2013 menjadi 46 kasus pada tahun 2014, kemudian meningkat lagi hingga mencapai 51 kasus pada tahun 2015. Jadi total kejadian BBLR yang lahir hidup di wilayah Tasikmadu dari tahun 2013 sampaitahun 2015 mencapai 122 kasus (Profil Kesehatan Karanganyar, 2015).

Selain BBLR, pola asuh gizi yang tidak tepat juga mempengaruhi status gizi anak dan dapat memicu terjadinya anemia. Saat bayi memasuki usia 2 sampai 4 bulan, terjadi pertumbuhan yang semakin pesat dan pembentukan hemoglobinpun semakin banyak. Ketika bayi berusia 4 bulan ke atas, cadangan besi mulai menurun, sedangkan kadar besi dalam ASI tidak bertambah. Oleh karena itu, setelah usia 6 bulan kebutuhan nutrisi dan besi tergantung pada MPASI (WHO, 2004). Alzain (2012), juga menyatakan bahwa selain gizi, riwayat sakit juga merupakan faktor pemicu terjadinya anemia. Kesehatan anak, sangat dipengaruhi oleh asupan nutrisi. Kekurangan zat besi memiliki dampak buruk pada kesehatan dan mempengaruhi kekebalan tubuh, Oleh karena itu, dalam rangka upaya mengoptimalkan pertumbuhan dan perkembangan anak usia golden age period, saat ini sangat diperlukan program dan implementasi nyata untuk mengendalikan anemia.

Amerika Serikat merupakan salah satu negara yang mempunyai program bagus terkait pengendalian kasus anemia pada bayi. Keberhasilan program ini tampak nyata, hal ini dapat dilihat dari hasil survey yang menunjukkan bahwa prevalensi anemia defisiensi besi di Amerika Serikat pada anak-anak usia 1 
Journal of Maternal and Child Health (2017), 2(3): 200-212

https://doi.org/10.26911/thejmch.2017.02.03.02

sampai 5 tahun hanya sekitar 1 sampai $2 \%$ (Donagh, et al, 2015). The American Academy of Pediatrics (AAP) dan Centers for Disease Control and Prevention (CDC) sudah menganjurkan untuk melakukan pemeriksaan hemoglobin ( $\mathrm{Hb}$ ) dan hematokrit (Ht) setidaknya satukali pada usia 912 bulan dan diulang 6 bulan kemudian pada usia 15-18 bulan ataupemeriksaan tambahan setiap 1 tahun sekali pada usia 25 tahun (Mahoney, 2016). Suplementasi besi juga diberikan kepada semua anak, dengan prioritas usia balita (0-5 tahun), terutama usia 0-2 tahun (IDAI, 2012). Akan tetapi, di Indonesia sampai saat ini masih belum membuat kebijakan terkait hal tersebut. Dalam hal ini, Amerika Serikat lebih menekankan pada aspek promotif dan preventif, sedangkan di Indonesia masih menekankan aspek kuratif dan rehabilitatif.

Implementasi yang berbeda dalam upaya pengendalian kasus anemia defisiensi besi antara Indonesia dan Amerika Serikat, serta pertimbangan terkait beberapa faktor resiko pemicu terjadinya anemia pada bayi, mendorong penulis tertarik untuk melakukan penelitian "Pengaruh Berat Badan Lahir, Riwayat Sakit dan Pola Asuh Gizi terhadap Kejadian Anemia dan Status Gizi pada Anak Usia Bawah Lima Tahun di Puskesmas Tasikmadu Kabupaten Karanganyar”.

\section{SUBJEK DAN METODE}

\section{Desain Penelitian}

Desain yang digunakan dalam penelitian ini adalah observasional analitik, dengan pendekatan kuantitatif, menggunakan case control study dan dengan menggunakan path analisis untuk mengetahui pengaruh variabel independen terhadap variabel dependen. Penelitian ini dilakukan di wilayah kerja Puskesmas Tasikmadu Kabupaten Karanganyar pada bulan Februari sampai April 2017.

\section{Populasi dan Sampling}

Populasi dalam penelitian ini adalah seluruh anak usia 6 sampai 60 bulan di Kabupaten Karanganyar. Sampel dalam penelitian sebesar 110 subjek dengan perbandingan antara kelompok kasus dan kelompok kontrol1:2. Pengambilan sampel dalam penelitian ini dilakukan dengan cara Fixed Desease Sampling, teknik ini merupakan pengambilan sampel pada balita dengan riwayat berat badan lahir rendah sebagai kasus dan balita dengan riwayat berat badan lahir normal sebagai kontrol. Kasus pada penelitian ini adalah semua anak usia 6 sampai 60 bulan dengan riwayat berat badan lahir rendah di wilayah kerja Puskesmas Tasikmadu Karanganyar.

Kontrol adalah semua anak usia 6 sampai 60 bulan dengan riwayat berat badan lahir normal di wilayah kerja Puskesmas Tasikmadu Karanganyar. Sedangkan teknik sampling yang digunakan dalam penelitian ini adalah purposive sampling.

\section{Variabel Penelitian}

Terdapat tujuh variabel dalam penelitian ini yang terdiri dari variabel dependen dan independen. Variabel dependen yaitu Anemia. Variabel independen meliputi berat badan lahir, income keluarga, pendidikan ibu, imunisasi, riwayat sakit dan pola asuh gizi

\section{Definisi Operasional}

Anemiadidefinisikan sebagai suatu keadaan dimana kadar hemoglobin ( $\mathrm{Hb}$ ) di dalam darah lebih rendah daripada nilai normal untuk kelompok orang yang bersangkutan. Anak usia 6 sampai 60 bulan dinyatakan anemia jika kadar Hb kurang dari $11 \mathrm{~g} / \mathrm{DL}$ (110 g/L) (Janus, 2016).

Berat badan lahir merupakan riwayat berat badan lahir anak yang terbagi menjadi dua kategori, yaitu riwayat berat badan lahir rendah $<2,500$ gram dan riwayat berat badan lahir normal $\geq 2,500$ gram. 
Income keluarga merupakan pendapatan yang dijadikan sumber perekonomian keluarga selama 1 bulan, dimana diketegorikan menjadi dua, yaitu keluarga dengan income rendah jika $\leq \mathrm{UMR}(\mathrm{Rp}$ 1,560,000) dan keluarga dengan income tinggi jika pendapatan 1 bulan > UMR (Rp $1,560,000)$.

Pendidikan ibu merupakan jenjang pendidikan formal terakhir yang telah ditamatkan oleh ibu balita. Pendidikan ibu terakhir termasuk dalam pendidikan rendah jika ibu hanya lulus Sekolah Dasar (SD), Madrasah Ibtidaiyah (MI) atau bentuk lain yang sederajat maupun Sekolah Menengah Pertama (SMP) dan Madrasah Tsanawiyah (MTs). Kategori pendidikan tinggi, jika ibu merupakan lulusan dari Sekolah Menengah Atas (SMA), Madrasah Aliyah (MA), Sekolah Menengah Kejuruan (SMK), dan Madrasah Aliyah Kejuruan (MAK), atau bentuk lain yang sederajat) dan pendidikan tinggi (mencakup program pendidikan diploma, sarjana, magister, spesialis, dan doktor yang diselenggarakan oleh perguruan tinggi.

Status imunisasi adalah imunisasi dasar dan imunisasi lanjutan yang telah diberikan sesuai dengan usia balita. Riwayat sakit merupakan riwayat sakit yang dialami oleh balita selama 1 bulan terakhir, seperti demam, diare, batuk, pilek, sesak, muntah, maupun penyakit lainnya baik dilakukan rawat inap maupun tidak.

Pola asuh gizi merupakan ketepatan praktik pemberian makanan atau pola pemberian gizi oleh ibu terhadap anak yang meliputi ketepatan dalam pemberian MPASI terdiri dari (usia pertama pemberian MP-ASI, jenis, jumlah dan frekuensi serta ragam/variasi MP-ASI yang diberikan kepada balita) disesuaikan dengan usia anak.

\section{Teknik Pengumpulan Data}

Pengumpulan data independen (berat badan lahir, income keluarga, pendidikan ibu, imunisasi, riwayat sakit dan pola asuh gizi) dilakukan dengan menggunakan kuesioner, sedangkan data pada variabel dependen (pemeriksaan kadar $\mathrm{Hb}$ balita) dilakukan oleh peneliti dengan menggunakan alat $\mathrm{Hb}$ meter. Teknik pengumpulan data dilakukan berdasarkan data yang diperoleh dari Dinas KesehatanKabupaten Karanganyar. Kemudian data tersebut diambil bersamaan dengan kegiatan Posyandu Balita di wilayah kerja Puskesmas Tasikmadu pada bulan Februari sampai dengan April 2017.

\section{Analisis Data}

Pengolahan dan analisis data menggunakan program Stata 13. Analisis data kuantitatif dilakukan secara univariatuntuk menampilkan data dalam bentuk distribusi frekuensi dari masing-masing variabel, yang akan di deskripsikan dalam frekuensi dan persentase (\%), bivariat (chi square) dengan menggunakan Confidence Interval (CI) sebesar 95\% ( $\alpha=0.05)$. Uji ini untuk mengetahui hubungan antara variabel idependen dan dependen dan analisis multivariat dilakukan dengan analisis jalur (path analysis) untuk mengetahui pengaruh langsung dan tidak langsung dari antara variabel independen terhadap variabel dependen. Analisis jalur merupakan teknik analisis yang digunakan untuk mengetahui pengaruh suatu variabel eksogen terhadap variabel endogen baik yang mempengaruhi secara langsung maupun tidak langsung.

\section{HASIL}

Karakteristik subjek penelitian ini ditunjukkan dalam bentuk jumlah dan persentase pada Tabel 1 yang meliputi riwayat berat lahir balita (BBLR dan tidak BBLR), tingkat pendidikan ibu ( $<$ SMA dan kategori $\geq$ SMA). Income keluarga (keluarga dengan 
income rendah dan keluarga dengan income tinggi).

Berdasarkan tabel 1 diketahui bahwa dalam penelitian ini 110 subjek penelitian terbagi menjadi kelompok kasus, yaitu 35 balita (31.8\%) dengan riwayat berat lahir
BBLR dan kontrol, yaitu 75 balita (68.2\%) dengan riwayat berat lahir normal sebagai kontrol. Ibu balita tersebut mayoritas mempunyai pendidikan $\geq$ SMA 86 (78.2\%) dan mayoritas balita $72(65.5 \%)$ berasal dari keluarga dengan income tinggi.

Tabel 1. Karakteristik subjek penelitian

\begin{tabular}{clcc}
\hline \multicolumn{1}{c}{ Karakteristik } & Kriteria & $\mathrm{N}$ & $\%$ \\
\hline Riwayat berat lahir balita & BBLR & 35 & 31.8 \\
& Tidak BBLR & 75 & 68.2 \\
Pendidikan ibu & < SMA & 24 & 21.8 \\
\multirow{2}{*}{ Income } & 2 SMA & 86 & 78.2 \\
& Rendah & 38 & 34.5 \\
\hline
\end{tabular}

Tabel 2. Distribusi frekuensi variabel penelitian

\begin{tabular}{|c|c|c|c|}
\hline \multicolumn{2}{|r|}{ Variabel } & \multirow[t]{2}{*}{$\mathbf{n}$} & \multirow[t]{2}{*}{$\%$} \\
\hline $\mathbf{1}$ & Income Keluarga & & \\
\hline & Rendah & 38 & 34.5 \\
\hline & Tinggi & 72 & 65.5 \\
\hline \multirow[t]{3}{*}{2} & Berat Badan Lahir & & \\
\hline & BBLR & 35 & 31.8 \\
\hline & Tidak BBLR & 75 & 68.2 \\
\hline \multirow[t]{3}{*}{3} & Pendidikan Ibu & & \\
\hline & $<$ SMA & 24 & 21.8 \\
\hline & $\geq$ SMA & 86 & 78.2 \\
\hline \multirow[t]{3}{*}{4} & Pola Asuh Gizi & & \\
\hline & Tidak Tepat & 30 & $27 \cdot 3$ \\
\hline & Tepat & 80 & 72.7 \\
\hline \multirow[t]{3}{*}{5} & Riwayat Sakit & & \\
\hline & Sehat & 78 & 70.9 \\
\hline & Sakit & 32 & 29.1 \\
\hline \multirow[t]{3}{*}{6} & Status Imunisasi & & \\
\hline & Tidak Lengkap & 23 & 20.9 \\
\hline & Lengkap & 87 & 79.1 \\
\hline \multirow[t]{3}{*}{7} & Kadar Hb & & \\
\hline & Tidak Anemia & 62 & 56.4 \\
\hline & Anemia & 48 & 43.6 \\
\hline
\end{tabular}

Distribusi frekuensi variabel penelitian melalui analisis univariat menjelaskan tentang gambaran umum masing-masing variabel yang diteliti meliputi income keluarga, berat badan lahir, pendidikan ibu, pola asuh gizi, riwayat sakit, status imunisasi dan kadar $\mathrm{Hb}$ balita. Hasil penelitian menunjukkan bahwa sebagian besar balita berasal dari keluarga dengan income tinggi, yaitu 72 subjek penelitian(65.5\%). Dalam penelitian ini, subjek penelitian terbagi menjadi dua, yaitu 35 balita (31.8\%) dengan riwayat berat lahir rendah dijadikan sebagai kasus dan 75 balita (68.2\%) dengan riwayat berat lahir normal sebagai kontrol. Sebagian besar ibu balita mempunyai riwayat pendidikan tinggi $\geq$ SMA 
yang terdiri dari 86 subjek penelitian(78.2\%). Mayoritas balita mendapatkan pola asuh gizi yang tepat sesuai dengan usia bayi, yaitu 80 subjek penelitian(72.7\%). 78 (70.9\%) dari 110 balita, dalam 3 bulanterakhir dalam kondisi sehat. Mayoritas balita 87 (79.1\%) sudah mendapatkan imunisasi lengkap 62 (56.4\%) balita dalam keadaan anemia.
Analisis bivariat dilakukan untuk melihat adanya hubungan variabel independen (income keluarga, berat badan lahir, pendidikan ibu, status imunisasi, riwayat sakit dan pola asuh gizi) terhadap variabel dependen (Anemia) yang dianalisis menggunakan uji chi-square.

\section{Tabel 3. Analisis bivariat pengaruh variabel independen terhadap kadar $\mathbf{H b}$}

\begin{tabular}{|c|c|c|c|c|c|c|c|c|c|}
\hline \multirow{3}{*}{ Variabel } & \multicolumn{4}{|c|}{ Kadar Hb } & & & \multirow{3}{*}{ OR } & \multirow{3}{*}{ CI (95\%) } & \multirow{3}{*}{$\mathrm{p}$} \\
\hline & \multicolumn{2}{|c|}{$\begin{array}{c}\text { Tidak } \\
\text { Anemia }\end{array}$} & \multicolumn{2}{|c|}{ Anemia } & \multicolumn{2}{|c|}{ Total } & & & \\
\hline & $\mathrm{n}$ & $\%$ & $\mathrm{n}$ & $\%$ & $\mathrm{~N}$ & $\%$ & & & \\
\hline \multicolumn{10}{|l|}{ Income } \\
\hline Rendah & 19 & 50.0 & 19 & 50.0 & 38 & 100 & 0.67 & $0.31-1.49$ & 0.328 \\
\hline Tinggi & 43 & 59.7 & 29 & 40.3 & 72 & 100 & & & \\
\hline \multicolumn{10}{|l|}{$\mathrm{BBL}$} \\
\hline BBLR & 12 & $34 \cdot 3$ & 23 & 65.7 & 35 & 100 & 0.26 & $0.11-0.69$ & 0.001 \\
\hline \multicolumn{10}{|l|}{ Pendidikan Ibu } \\
\hline$<$ SMA & 10 & 41.7 & 14 & 58.3 & 24 & 100 & 0.47 & $0.19-1.17$ & 0.101 \\
\hline$\geq$ SMA & 52 & 60.5 & 34 & 39.5 & 86 & 100 & & & \\
\hline \multicolumn{10}{|l|}{ Status } \\
\hline \multicolumn{10}{|l|}{ Imunisasi } \\
\hline Tidak Lengkap & 16 & 69.6 & 7 & 30.4 & 23 & 100 & 2.04 & $0.76-5.44$ & 0.151 \\
\hline Lengkap & 46 & 52.9 & 41 & 47.1 & 87 & 100 & & & \\
\hline \multicolumn{10}{|l|}{ Riwayat } \\
\hline \multicolumn{10}{|l|}{ Sakit } \\
\hline Sehat & 59 & 75.6 & 19 & 24.4 & 78 & 100 & 30.02 & $8.21-109.73$ & $<0.001$ \\
\hline Sakit & 3 & 9.4 & 29 & 90.6 & 32 & 100 & & & \\
\hline \multicolumn{10}{|l|}{ Pola Asuh } \\
\hline Gizi & & & & & & & & & \\
\hline Tidak Tepat & 3 & 10.0 & 27 & 90.0 & 30 & 100 & 0.40 & $0.01-0.14$ & $<0.001$ \\
\hline Tepat & 59 & 73.8 & 21 & 26.3 & 80 & 100 & & & \\
\hline
\end{tabular}

Hasil analisis bivariat menunjukkan bahwa beberapa variabel penelitian yang mempunyai hubungan bermakna dengan kejadian anemia pada balita yaitu berat badan lahir $(\mathrm{p}=0.001)$, riwayat sakit $(\mathrm{p}=<0.001)$ dan pola asuh gizi ( $\mathrm{p}=<0.001)$, sedangkan income keluarga $(\mathrm{p}=0.328)$, pendidikan ibu $(\mathrm{p}-$ $=0.101)$ dan status imunisasi $(p=0.151)$ menunjukkan tidak adanya hubungan yang bermakna.Analisis data dilanjutkan dengan analisis jalur. Analisis jalur dilakukan untuk mengetahui pengaruh antara variabel-variabel independen terhadap variabel dependen baik secara langsung maupun tidak langsung, de- ngan hasil bahwa anemia dipengaruhi secara langsung olehriwayat sakit $(b=2.51, \mathrm{CI} 95 \%=$ 1.06 sampai 3.95, $\mathrm{p}=0.001$ ), pola asuh gizi $(b=-1.86$, CI 95\%= -3.39 sampai -0.39, $\mathrm{p}=$ o.013)dan berat badan lahir dengan nilai $(\mathrm{b}=$ -0.97, CI95\%= 2.06 sampai 0.13, p= 0.083).

Sedangkan riwayat sakit dipengaruhi oleh income keluarga $(b=-0.90$, CI 95\% $=-1.77$ sampai -0.24, p=0.044). Riwayat sakit dipengaruhi oleh berat badan lahir $(b=-0.11, C I$ $95 \%=-1.98$ sampai $-0.22, p=0.014)$. Imunisasi dipengaruhi oleh income keluarga $(b=$ 1.09, CI 95\%=0.07 sampai 2.12, $\mathrm{p}=0.037$ ). Imunisasi dipengaruhi oleh pendidikan ibu 
Journal of Maternal and Child Health (2017), 2(3): 200-212

https://doi.org/10.26911/thejmch.2017.02.03.02

$(b=1.67$, CI $95 \%=0.61$ hingga 2.74, $\mathrm{p}=$ hi oleh pendidikan ibu $(b=1.29$, CI95\% $=0.35$ 0.002). Pola asuh gizi dipengaruhi oleh pen- hingga 2.22, $\mathrm{p}=0.007$ ). Hasil dari analisis didikan ibu $(b=1.09$, CI95\%= 0.14 hingga jalur dapat lihat tabel 4 .

2.04, $\mathrm{p}=0.024)$. Income keluarga dipengaru-

Tabel 4. Hasil analisis jalur faktor-faktor yang mempengaruhi kejadian anemia di Puskesmas Tasikmadu Kabupaten Karanganyar

\begin{tabular}{|c|c|c|c|c|c|}
\hline \multirow[b]{2}{*}{ Variabel dependen } & \multirow[b]{2}{*}{ Variabel independen } & \multirow[b]{2}{*}{$\mathbf{O R}$} & \multicolumn{2}{|c|}{ CI (95\%) } & \multirow[b]{2}{*}{$\mathbf{p}$} \\
\hline & & & $\begin{array}{c}\text { Batas } \\
\text { Bawah }\end{array}$ & $\begin{array}{l}\text { Batas } \\
\text { Atas }\end{array}$ & \\
\hline \multicolumn{6}{|l|}{ Pengaruh Langsung } \\
\hline \multirow[t]{3}{*}{ Anemia } & Riwayat SakitPola Asuh & 2.51 & 1.06 & 3.95 & 0.001 \\
\hline & Gizi Baik & -1.89 & -3.39 & -0.39 & 0.013 \\
\hline & BBL Normal & -0.97 & -2.06 & 0.13 & 0.083 \\
\hline \multicolumn{6}{|l|}{ Tidak Langsung } \\
\hline \multirow[t]{2}{*}{ Riwayat Sakit } & Income $\geq \mathrm{UMK}$ & -0.90 & -1.78 & -0.24 & 0.044 \\
\hline & BBL Normal & -1.10 & -1.99 & -0.22 & 0.014 \\
\hline \multirow[t]{2}{*}{ Imunisasi } & Income $\geq$ UMK & 1.09 & 0.07 & 2.12 & 0.037 \\
\hline & Pendidikan $\geq$ SMA & 1.68 & 0.62 & 2.73 & 0.002 \\
\hline Pola Asuh Gizi & Pendidikan $\geq$ SMA & 1.09 & 0.49 & 0.14 & 0.024 \\
\hline Income & Pendidikan $\geq$ SMA & 1.28 & 0.35 & 2.22 & 0.007 \\
\hline \multirow{2}{*}{$\begin{array}{l}\text { Log Likelihood = } \\
\text { AIC }\end{array}$} & $-285 \cdot 34825$ & & & & \\
\hline & 598.69 & $\mathrm{BIC}$ & 636.50 & & \\
\hline
\end{tabular}

PEMBAHASAN

1. Pengaruh antara riwayat sakit terhadap kejadian anemia pada balita

Terdapat pengaruh positif, langsung dan secara statistik signifikan antara riwayat sakit terhadap kejadian anemia. Menurut Alzain (2012), riwayat sakit merupakan faktor pemicu terjadinya anemia.

Salah satu contoh penyakit yang bisa menyebabkan anemia adalah diare. Dalam penelitian ini, beberapa balita mendapatkan pola asuh gizi tidak tepat dan karenanya balita tersebut menderita diare. Diare yang terlalu sering diderita oleh balita, akan menurunkan kemampuan usus dalam absorbsi nutrisi (Wahyuni, 2004). Hasil penelitian juga menunjukkan bahwa, mayoritas balita yang mengalami infeksi saluran pernafasan atas (ISPA) juga akan mengalami penurunan nafsu makan dan sebagian dari mereka cenderung gumoh setelah makan ataupun minum susu, hal ini tentunya berpengaruh terhadap kecukupan asupan nutrisi, sehingga dapat meningkatkan resiko terjadinya anemia.

Habibet al., (2016) menyatakan bahwa kekurangan zat besi dalam tubuh dapat lebih meningkatkan resiko terserang penyakit infeksi. Seseorang yang menderita defisiensi besi (terutama balita) lebih mudah terserang mikroorganisme. Berdasarkan hasil penelitian, jumlah bayi dari keluarga miskin di London yang menderita penyakit bronchitis dan gastroenteritis menjadi berkurang setelah mereka mendapat terapi zat besi. Di Alaska, penyakit diare dan saluran pernafasan juga lebih umum ditemui pada orang-orang eskimo dan orang-orang asli yang menderita defisiensi besi.

\section{Pengaruh antara pola asuh gizi terhadap kejadian anemia pada balita}

Terdapat pengaruh negatif, langsung dan secara statistik signifikan antara pola asuh gizi terhadap kejadian anemia. Ketepatan 
pemberian MP-ASI sesuai dengan usia anak merupakan faktor penting yang dapat mempengaruhi kadar $\mathrm{Hb}$. Kemampuan bayi baru lahir untuk mencerna karbohidrat, lemak dan protein diatur oleh beberapa enzim. Akan tetapi, karena sistem pencernaan bayi baru lahir belum matang ada beberapa enzim yang belum diproduksi, yaitu enzim amilase, yang diproduksi oleh kelenjar Saliva setelah 3 bulan dan diproduksi oleh pankreas pada usus sekitar 6 bulan. Enzim ini diperlukan untuk mengubah karbohidrat menjadi maltose. Enzim lipase juga diproduksi oleh pankreas pada usus sekitar 6 bulan. Enzim ini diperlukan untuk mencerna lemak, oleh karena itu untuk memaksimalkan absorbsi nutrisi ketepatan pemberian MP-ASI sesuai usia anak sangatlah penting.

Pada waktu lahir, zat besi dalam tubuh kurang lebih $75 \mathrm{mg} / \mathrm{kg}$ berat badan dan reserve zat besi sekitar 25\%. Pada umur 6-8 mg, terjadi penurunan kadar $\mathrm{Hb}$ dari yang tertinggi pada waktu lahir menjadi rendah. Kadar $\mathrm{Hb}$ menurun merupakan akibat dari penggantian sel-sel darah merah yang diproduksi sebelum lahir diganti dengan sel-sel darah merah baru yang diproduksi sendiri oleh bayi. Akibatnya, pada usia 6 bulan cadangan besi dan ASI tidak cukup lagi memenuhi kebutuhan bayi(WHO, 2004). Setelah usia 6 bulan kebutuhan nutrisi dan besi tergatung dari pemberian MP-ASI (Lewa, 2016). Hasil survei menunjukkan bahwa salah satu penyebab terjadinya anemia pada anak usia 6 sampai 24 bulan di Indonesia adalah rendahnya mutu MP-ASI, sehingga beberapa zat gizi mikro terutama zat besi $(\mathrm{Fe})$ dan Seng ( $\mathrm{Zn})$ tidak dapat mencukupi kebutuhan energi. Padahal disisi lain, bayi yang berumur dibawah 1 tahun dan anak berumur 6-16 tahun, membutuhkan zat besi sama banyaknya dengan laki-laki dewasa (IDAI, 2011)
Selain itu, ketidak sesuaian pola asuh gizi juga dapat membentuk karakter anak menjadi sulit makan, (Nafratilawati, 2014). Sebuah research dariThe Gateshead Millenium Baby Study pada tahun 2006 di Inggris menyebutkan $20 \%$ orang tua melaporkan anaknya mengalami masalah makan, ngan prevalensi tertinggi anak hanya mau makan makanan tertentu. Studi di Italia mengungkapkan bahwa pada awalnya hanya $6 \%$ bayi yang mengalami kesulitan makan, kemudian meningkat 2540\% pada saat fase akhir pertumbuhan. Hasil penelitian Karakiet al., (2016), menyatakan bahwa terdapat hubungan antara pola asuh ibu dengan perilaku sulit makan.

\section{Pengaruh berat badan lahir terha- dap kejadian anemia pada balita}

Terdapat pengaruh negatif, langsung dan secara statistik mendekati signifikan antara berat badan lahir terhadap kejadian anemia. Sebagian besar proses transfer zat besi dari ibu ke janin terjadi pada bulanbulan akhir kehamilan, dengan demikian bayi prematur dan BBLR rentan mengalami anemia (WHO, 2004).

BBLR mempunyai risiko 3,34 kali lebih besar untuk mengalami status gizi kurang dibandingkan dengan anak yang tidak BBLR. Bayi yang lahir dengan BBLR mempunyai reserve zat besi yang lebih rendah dari bayi normal yang lahir dengan berat badan cukup, tetapi rasio zat besi terhadap berat badan adalah sama. Pertumbuhan bayi yang lahir dengan BBLR lebih cepat dari pada bayi normal, sehingga reserve zat besi lebih cepat habis. Oleh sebab itu, kebutuhan zat besi pada bayi BBLR lebih besar dari pada bayi normal. Jika bayi BBLR mendapat makanan yang cukup mengandung zat besi, maka pada usia 9 bulan kadar Hb akan dapat menyamai bayi yang normal (Arnisam, 2007). 
Journal of Maternal and Child Health (2017), 2(3): 200-212

https://doi.org/10.26911/thejmch.2017.02.03.02

\section{Pengaruh antara income keluarga terhadap status imunisasi balita}

Terdapat pengaruh positif, langsung dan secara statistik signifikan antara income keluarga terhadap status imunisasi. Hasil penelitian tersebut sesuai dengan penelitian yang dilakukan oleh Agrawal (2014), yang menyatakan bahwa salah satu faktor yang memiliki dampak signifikan terhadap status imunisasi balita adalah income keluarga. Papachrisanthou (2016) menyatakan bahwa keluarga dengan income tinggi lebih patuh terhadap ketepatan jadwal imunisasi anaknya.

Dalam penelitian ini, mayoritas ibu balita bekerja di pabrik maupun wiraswasta, sedangkan program imunisasi di Puskesmas selalu terjadwalkan pada saat jam kerja Puskesmas (pagi). Hal inilah yang membuat sebagian balita tidak mendapatkan imunisasi lengkap, karena memberikan imunisasi di Bidan Praktik Mandiri harus mengeluarkan biaya mandiri.

\section{Pengaruh antara pendidikan ibu terhadap status imunisasi balita}

Terdapat pengaruh positif, langsung dan secara statistik signifikan antara pendidikan terhadap status imunisasi. Adeloye et al., (2017) membuktikan bahwa tingkat pendidikan ibu yang rendah menjadi salah datu faktor yang menyebabkan menurunnya cakupan imunisasi di Nigeria. Hal ini dikaitkan dengan kemampuan ibu terhadap penerimaan informasi terkait pentingnya imunisasi bagi anaknya. Awadhet al.,(2015) juga menyatakan bahwa balita yang mempunyai orang tua dengan pendidikan rendah harus lebih diperketat pemantauannya terhadap ketepatan pemberian imunisasi sesuai jadwal.

\section{Pengaruh antara income keluarga terhadap kejadian anemia pada balita melalui variabel antara riwayat sakit}

Terdapat pengaruh negatif, tidak langsung (melalui variabel antara riwayat sakit) dan secara statistik signifikan antara income keluarga terhadap kejadian anemia.

Emerson and Savage (2017) menyatakan bahwa anak-anak yang berasal dari keluarga dengan income rendah dan menengah lebih beresiko mengalami penyakit infeksi, seperti ISPA, diare dan demam. Hal ini dapat meningkatkan resiko terjadinya anemia. Berdasarkan hasil riset, jumlah bayi dari keluarga miskin di London yang menderita bronchitis dan gastroenteritis menjadi berkurang setelah mereka mendapat terapi zat besi. Di Alaska, penyakit diare dan saluran pernafasan lebih umum ditemui pada orang-orang eskimo dan orang-orang asli yang menderita defisiensi besi (Habibet al., 2016).

\section{Pengaruh antara berat badan lahir terhadap kejadian anemia pada balita melalui variabel antara riwayat sakit}

Terdapat pengaruh negatif, tidak langsung (melalui variabel antara riwayat sakit) dan secara statistik signifikan antara berat badan lahir terhadap kejadian anemia. Studi Life Course Epidemiology membuktikan bahwa bayi dengan riwayat berat badan lahir rendah lebih beresiko mempunyai riwayat sakit yang tinggi baik saat balita, remaja, dewasa, bahkan pada saat memasuki lansia. Joko Wahyu Wibowo pada tahun 2011 melakukan pengkajian terhadap kejadian penyakit jantung koroner sebagai dampak dari berat bayi lahir rendah (mengkaitkan kejadian saat lahir dengan ancaman penyakit dalam fase kehidupan berikutnya). Kesimpulan riset ini yaitu bayi dengan berat lahir rendah merupakan faktor risiko penyakit jantung koroner. BBLR juga sering lebih mudah mengalami infeksi.

Penelitian Pondanget al., (2015) juga mengkaji efek BBLR dengan resiko penyakit asma pada level kehidupan berikutnya 
(anak). Sebagian besar anak dengan riwayat BBLR menunjukan fungsi paru yang buruk dan meningkatkan resiko asma pada anak.Hasil penelitian menunjukkan bahwa BBLR memiliki hubungan terhadap angka kejadian asma pada anak. Pada BBLR seringkali disertai dengan immaturitas organ tubuh seperti pada organ pernapasan. Riset ini mendukung kajian epidemiologi sepanjang hayat bahwa kondisi kesehatan pada level perkembangan awal berpengaruh terhadap resiko terjadinya penyakit kronis pada level perkembangan berikutnya.

Alzain (2012) menyatakan bahwa riwayat sakit juga merupakan faktor pemicu terjadinya anemia, karena kekurangan zat besi berhubungan erat dengan kerusakan kemampuan fungsional dari mekanisme kekebalan tubuh yang penting untuk menahan masuknya penyakit infeksi.

\section{Pengaruh antara pendidikan ibu} terhadap kejadian anemia pada balita melalui variabel antara income keluarga dan pola asuh gizi.

Terdapat pengaruh positif, tidak langsung (melalui variabel antara pola asuh gizi dan income keluarga) dan secara statistik signifikan antara pendidikan ibu terhadap kejadian anemia. Ketepatan pemberian MP-ASI pada anak balita salah satunya dipengaruhi oleh faktor sosial ekonomi, antara lain pendidikan ibu serta kondisi ekonomi orangtua secara keseluruhan (income keluarga). Hasil penelitian yang dilakukan oleh Putriet al., (2015), menunjukan bahwa terdapat hubungan antara pendidikan ibu, pekerjaan ibu, pendapatan keluarga, jumlah anak dan pola asuh gizi ibu terhadap status gizi anak balita. Penelitian ini menyatakan bahwa mayoritas ibu balita yang mempunyai riwayat pendidikan tinggi juga mempunyai income yang tinggi pula.

WHO Global Strategy for Feeding Infant and Young Children pada tahun 2003 merekomendasikan agar pemberian MPASI memenuhi 4 syarat, yaitu tepat waktu, adekuat (MP-ASI memiliki kandungan energi, protein dan mikronutrien yang dapat memenuhi kebutuhan makronutrien dan mikronutrien bayi sesuai usianya), aman dan diberikan dengan cara yang benar dengan memperhatikan rasa lapar dan kenyang seorang anak. Hal-hal yang perlu diperhatikan saat memberikan makanan, antara lain tahapan pemberian MPASI, jumlah dan frekuensi dan variasi pemberian makan (Jayanti, 2014).

Oleh karena itu, ibu yang mempunyai pendidikan tinggi cenderung lebih mudah mengerti, mencari berbagai informasi dan memahami pentingnya ketepatan pemberian MP-ASI, sehingga tidak terpengaruh oleh tradisi. Ragam variasi MP-ASI setiap harinya (sesuai dengan usia anak), juga sangat dipengaruhi oleh income keluarga. Semakin tinggi income keluarga, maka MPASI yang diberikan cenderung lebih bervariasi.

\begin{tabular}{l}
\hline REFERENCE \\
\hline Abdullah AZ, A. Arsunan Arsin, Lidyawati \\
Dahlan (2012). Risk Factors of Shig- \\
ellosis Diarrhea in Children Under \\
Five Years Old. Jurnal Kesehatan \\
Masyarakat 7(1):16-21. \\
Abraham DDL, Nova H Kapantow, Mau- \\
reen I. Punuh (2016). Hubungan \\
Antara Pola Asuh Ibu dengan Status \\
Gizi Anak Umur 2-5 Tahun di Wila- \\
yah Kerja Puskesmas Kombos Kota \\
Manado. Fakultas Kesehatan Masya- \\
rakat Universitas Sam Ratulangi Ma- \\
nado. \\
Adeloye D, Wura Jacobs, Ann O. Amuta, \\
Oluwatomisin Ogundipe, Oluwaseun \\
Mosaku, Muktar A. Gadanya, Gbola- \\
han Oni (2017). Coverage and deter- \\
minants of childhood immunization \\
in Nigeria: A systematic review and
\end{tabular}


meta-analysis. Vaccine 35 (22): 28712881.

Agrawal SC, Anita Kumari. Immunization status of children and the influence of social factors: A hospital based study in western Uttar Pradesh. Pediatric Infectious Disease 6(1):25-30.

Al Hasawi Z, M, Sami A. Al-Rehali, Amani M. Mahros, Ali M. Al-Sisi, Khalid D. Al-Harbi, Ahmed M. Yousef. 2015. High prevalence of iron deficiency anemia in infants attending a wellbaby clinic in northwestern Saudi Arabia. Saudi Medical Journal 36(9): 1067-1070.

Al Awadh, Hassali MA, Bux SH (2015). Factors Affecting Immunization Timeliness In Malaysia. Value in Health 18(3) : A104.

Alzain B (2012). Anemia and Nutritional Status of PreSchool Children in North Gaza, Palestine. International Journal of Scientific and Technology Research 1(11):86-91.

Arnisam (2007). Hubungan Berat Badan Lahir Rendah (BBLR) dengan status gizi anak usia 6-24 bulan. available at http://etd.repository.ugm.ac.id. Diakses tanggal 5 Desember 2016.

Artini PP (2015). Penetapan Kadar Hemoglobin Cara Sahli.

Baso I S (2010). Konsep Penelitian Ex-Post Facto. Jurnal Pendidikan Matematika 1(2):1-16.

Black RE, Simon Cousens, Hope L Johnson, Joy E Lawn, Igor Rudan, Diego G Bassani, Prabhat Jha, Harry Campbell, Christa Fischer Walker, Richard Cibulskis, Thomas Eisele, Li Liu (2010). Global, Regional, and National Causes of Child Mortality in 2008: a Systematic Analysis 375 (9730): 1969-1987.

Ciptaningtyas R, Arif Sumantri, M Arbi Ramadhan (2012). Evaluation on
Failure Weight Gain among Toddlers of Low Economy Family After Complementary Biscuits Feeding Jurnal Kesehatan Masyarakat Nasional 7(5):227-232.

Depkes (2016). Situasi Imunisasi di Indonesia. Pusat Data dan Informasi Kementerian Kesehatan RI. ISSN 24427659.

Dinkes Prov. Jateng (2014). Profil Kesehatan Provinsi Jawa Tengah Tahun 2014.

Domellof M, Christian Braegger, Cristina Campoy, Virginie Colomb, Tamas Decsi, Mary Fewtrell, Iva Hojsak, Walter Mihatsch, Christian Molgaard, Raanan Shamir, Dominique Turck, Johannes V Goudeover (2014). Iron Requirements of Infants and Toddlers. J Pediatr Gastroenterol Nutrition 58(1):119-129.

Donagh MM, PharmD Ian Blazina, Tracy Dana, Amy Cantor, Christina Bougatsos (2015). Routine Iron Supplementation and Screening for Iron Deficiency Anemia in Children Ages 6 to 24 Months: A Systematic Review to Update the U.S. Preventive Services Task Force Recommendation. National Center for Biotechnology Information, U.S. National Library of Medicine.

Donnersberger AB (2011). Blood Testing. Laboratory Exercise.

Emerson E and Amber Savage (2017). Acute Respiratory Infection, Diarrhoea and Fever in Young Children At-Risk of Intellectual Disability in 24 Low and Middle Income Countries. Public Health142:85-93.

IDAI (2011). Suplementasi Besi untuk Anak. Ikatan Dokter Anak Indonesia.

HabibMA, Kirsten Black, Sajid B Soofi, Imtiaz Hussain, Zaid Bhatti, Zulfiqar A. Bhutta, Camille RGreenow (2016). 
Prevalence and Predictors of Iron Deficiency Anemia in Children under Five Years of Age in Pakistan, A Secondary Analysis of National Nutrition Survey Data 2011-2012. PLOS ONE 11(5):1-13

Janus J, Johns Hopkins, Sarah K. Moerschel (2016). American Academy of Family Physicians 81(2):1463-1471. Jayanti EN (2015). Hubungan Antara Pola Asuh Gizi dan Konsumsi Makanan dengan Kejadian Stunting pada Anak Balita Usia 6-24 Bulan.

Karaki BK, Rina Kundre Michael Karundeng (2016). Hubungan Pola Asuh Ibu dengan Perilaku Sulit Makan pada Anak Usia Prasekolah (3-5 tahun) di Taman Kanak-Kanak Desa Palelon Kec. Modoinding Minahasa Selatan. ejournal Keperawatan (e-Kp) 4(1):1-7.

Kemenkes RI (2011). Standar Antopometri Penilaian Status Gizi Anak.

Kemenkes RI (2013). Laporan Akuntabilitas Kinerja Kementrian Kesehatan Tahun 2013.

Kemenkes RI (2016). Profil Kesehatan Indonesia Tahun 2015.

Kemenkes RI (2016). Tahun 2015, Pemantauan Status Gizi Dilakukan di Seluruh Kabupaten/Kota di Indonesia.

Kuhu A, Maureen I. Punuh, Nova H. Kapantow (2016). Hubungan Antara Pola Asuh Ibu dengan Status Gizi Balita di Wilayah Kerja Puskesmas Kakas. Fakultas Kesehatan Masyarakat Universitas Sam Ratulangi Manado.

Lewa AF (2016). Faktor-Faktor yang Berhubungan dengan Status Gizi pada Balita Usia 6-23 Bulan di Kelurahan Pantoloan Boya Wilayah Kerja Puskesmas Pantoloan. Jurnal Status Gizi 6(1):9-16.
Mahoney DH (2016). Iron Deficiency in Infants and Young Children: Screening, Prevention, Clinical Manifestations, and Diagnosis.

Mufida L, Tri D Widyaningsih, Jaya M Maligan (2015). Prinsip Dasar Makanan Pendamping Air Susu Ibu (MPASI) untuk Bayi 6 - 24 Bulan: Kajian Pustaka. Jurnal Pangan dan Agroindustri 3(4):1646-1651.

Muliati DD, Amatus Y Ismanto, Reginus Malara (2014). Hubungan Keluarga Sadar Gizi dengan Status Gizi Balita di DesaMopuya Selatan Kecamatan Dumoga Utara KabupatenBolaang Mongondow.

Murti B (2013). Desain dan Ukuran Sampel untuk Penelitian Kuantitatif dan Kualitatif di Bidang Kesehatan. Yogyakarta: Gajah Mada University Press Hal : 119.

Nafratilawati M (2014). Hubungan Antara Pola Asuh dengan Kesulitan Makan pada Anak Pra Sekolah (3-5 Tahun) di TK Leyangan Kabupaten Semarang.

Norsiah W (2015). Perbedaan Kadar Hemoglobin dengan menggunakan Metode Sianmethhemoglobin dan Tanpa Sentrifugasi pada Sampel Leukositosis. Medical Laboratory Technology Journal 1(2):72-83.

Nur A, Nelly Marissa (2014). Breastfeeding History with Infectious Disease in Toddlers9(2):144-149.

Papachrisanthou MM, Rebecca A. Lorenz, Deborah G. Loman (2016). Increasing Immunization Adherence Among Infants of Low-income Parents: The Effects of Visually Enhanced Education. The Journal for Nurse Practitioners12(5):304-310.

Presiden RI (2003). Undang-Undang Republik Indonesia Nomor 20 Tahun 
2003 Tentang Sistem Pendidikan Nasional.

Pasricha SR (2014). Anemia: a Comprehensive Global Estimate. Blood Journal. The American Society of Hematology 123(5): 611-612.

Patil PJ, Girish VT, Sarika PP (2013). Variability and Accuracy of Sahli's Method in Estimation of Haemoglobin Concentration. National Journal of Integrated Research in Medicine 4(1): 38-44.

Permenkes (2013). Peraturan Menteri Kesehatan Republik Indonesia Nomor 42 (2013) tentang Penyelenggaraan Imunisasi.

Putri RF, Delmi Sulastri, Yuniar Lestari. 2015.Faktor-Faktor yang Berhubungan dengan Status Gizi Anak Balita di Wilayah Kerja Puskesmas Nanggalo Padang. Jurnal Kesehatan Andalas 4(1):254-261.

Short MW and Jason E Domagalski (2013). Iron Deficiency Anemia: Evaluation and Management. American Family Physician 87(2):98-104.

SjarifDR, Klara Yuliarti, Endang D Lestari, I Gusti L Sidiartha, Sri SNasar Maria Mexitalia (2015).
Rekomendasi Praktik Pemberian Makan Berbasis Bukti pada Bayi dan Batita di Indonesia untuk Mencegah Malnutrisi. Rekomendasi Ikatan Dokter Anak Indonesia.

Supariasa, I Dewa Nyoman (2012). Penilaian Status Gizi. Jakarta : EGC Hal : 39-42.

Unicef (2016). Paket Konseling: Pemberian Makan Bayi dan Anak.

Veria VA dan Mubarokah, K (2012). Peran Status Gizi TerhadapKecerdasan Kognitif pada masa Golden Age Period. Fakultas KesehatanUniversitas Dian Nuswantoro Semarang.

Wahyuni AS (2004). Anemia Defisien Besi Pada Balita.

WHO (2004). Guiding Principles for Feeding NonBreastfed Children 6-24 Months of Age.

WHO (2007). Assessing The Iron Status of Populations.

Zuffo CRK, Mônica M Osório, Cesar A Taconeli, Suely T Schmidt, Bruno H.C da Silvac, Cláudia C.B Almeidaa (2016). Prevalence and Risk Factors of Anemia in Children. Jornal de Pediatria 92(4):353-360. 